\title{
Residential Indoor Radon Assessment in the Vicinity of some Dumpsites in Lagos, Nigeria
}

\section{1'OLAOYE, MA; *2ADEMOLA, AK; ${ }^{3}$ JEGEDE, O}

\author{
${ }^{I}$ Department of Physics. Lagos State University, Nigeria \\ ${ }^{*}$ Physical Sciences Department, Bells University of Technology, Ota, Nigeria \\ ${ }^{3}$ Department of Physics, Federal University of Agriculture, Abeokuta, Nigeria \\ *Corresponding Author Email: drakademola@yahoo.com; Tel: +2347031921302; Other Authors Email:bigfolu@yahoo.com; Tel: \\ +23480289700077; Email: jegede.oluwaseyi@yahoo.com; Tel: +2348057170507
}

\begin{abstract}
Dumpsites in Nigeria are generally open and significantly elevate the pollution and contamination level of the total environment. Indoor radon was measured with CR-39 detectors in some buildings in the vicinity of dumpsites in Lagos, Nigeria. Eight (8) dumpsites (4 dormant and 4 active dumpsites) were chosen for this study. Detectors were exposed in 50 houses randomly selected within 0 and $100 \mathrm{~m}$ away from the dumpsites. The detectors were exposed for 3 months. They were then retrieved and etched in a $6 \mathrm{M} \mathrm{NaOH}$ solution in a water-bath at a temperature of $90^{\circ} \mathrm{C}$ for 3 hours. Tracks were counted using a semi-automatic system with a DCE camera mounted on a microscope and connected to a PC. Radon concentration ranged from $24.00 \pm 4.86$ to $656.00 \pm 131.20 \mathrm{Bqm}^{-3}$ in the active dumpsites. Mean concentrations were $120.3 \pm 24.0,257 \pm 51.4,179.8 \pm 33.6$, and $131.5 \pm 19.4$, respectively in Oke-Odo, MRF, Olusosun, and Solus-3. In the dormant sites, concentration ranged from $16 \pm 3.2$ to $931 \pm 186.3 \mathrm{Bqm}^{-3}$ having means of $194.17 \pm 38.80,206.75 \pm 41.33,223.25 \pm 44.69$, and $334 \pm 66.85 \mathrm{Bqm}^{-3}$, respectively in Oke-Afa, Solus- 1 , Solus-2, and Solus-4. The annual effective dose and cancer risk in the active and dormant dumpsites were $(3.60 \mathrm{mSv}, 8.97$ per million person-yearly) and (4.53 mSv, 12.47 per million person-yearly), respectively. This study revealed some high value of radon concentrations in some houses close to the dormant dumpsites than in the active dumpsites. This is unsafe and can cause severe health issues in the long term.
\end{abstract}

\section{DOI: https://dx.doi.org/10.4314/jasem.v25i1.2}

Copyright: Copyright (C) 2021 Olaoye et al. This is an open access article distributed under the Creative Commons Attribution License (CCL), which permits unrestricted use, distribution, and reproduction in any medium, provided the original work is properly cited.

Dates: Received: 02 October 2020; Revised: 26 November 2020; Accepted: 12 December 2020

Keywords: Radon, dumpsites, Olusosun, CR-39, buildings, Lagos state, SOLUS

Radiation is omnipresent and is inevitable for human beings (Benson and Ugbede, 2018). Sources of exposure vary from nuclear power plants, medical diagnosis, and treatment, radiofrequency signals, and activities such as production, mining, agricultural practices, and radioactive waste disposal that is continuous(Grganić et al., 2020).

Radon is a colourless and odourless gas with a halflife of 3.82 days (Rasouli and Mamkhosravi, 2018). Radon accounted for about $80 \%$ of the natural radiation people are exposed to (UNSCEAR, 2020). Various epidemiological researches have shown that radon is the cause of lung cancer in non-smokers (Kim et al., 2016; Ajrouche et al., 2018; Shankar et al., 2019; Corrales et al., 2020). It has also been experimentally revealed that radon at any level can cause genetic disorder (Ciorba et al., 2017; Stanley et al., 2017). Radon progenies $\left({ }^{218} \mathrm{P} 0\right.$ and $\left.{ }^{214} \mathrm{Po}\right)$ react with the biological tissue and cause damages to the cells and even DNA and chromosomes causing different health problems. The concentration of indoor radon depends on many factors such as the geological and geophysical orientation of the area, building materials for construction, meteorological variation, and outdoor radon concentration among other factors (Kurmar et al., 2017; Dai et al., 2019). Dumpsite is a widespread land where waste materials are deposited. They are generally open and exposed directly to the atmosphere. They can significantly increase the pollution and contamination of the environment if not properly managed (Zhang et al., 2019). The risk with disposal of municipal solid waste MSW in landfills in Lagos is a serious issue that needs appropriate attention. The knowledge of radon emanation in dumpsites is imperative to assess, monitor, evaluate, and mitigate through a radiation emergency response plan. This work aims at the measurement of radon concentrations in residential buildings in the vicinity of the dumpsites to estimate the health hazard to the residents and/or scavengers.

\section{MATERIALS AND METHODS}

Study Area: Lagos is a multinational and multi-ethnic city in South-Western, Nigeria. Its geographical 
location is between latitudes $6.451^{\circ} \mathrm{N}$ and longitudes $3.6218{ }^{\circ} \mathrm{E}$ (Adegboyega et al., 2017). Lagos is highly inhabited; resulting in an enormous consumption of goods and services, and consequently, a massive amount of waste generated. The geological map of Lagos is shown in Figure 1.

Selection of Dumpsites: Seventeen (17) dumpsites are being managed by the Lagos Waste Management Authority (LAWMA). Twelve (12) of these dumpsites are dormant while five (5) are active. Eight (8) dumpsites were selected for this study (four active and four dormant dumpsites). The choice of these dumpsites was based on factors such as type of waste collected, proximity to dwellings, life span, and recommendation by LAWMA. The selected dumpsites are active; (Olusosun, Solus-3, Material Recovery Facility MRF and Oke -Odo) and dormant dumpsites (Solus -1, Solus-2, Solus-4, and Oke- Afa).
Dwelling Selection and Detector Placement: Fifty (50) dwellings were selected randomly within $100 \mathrm{~m}$ from the dumpsites. Radon measurement was undertaken using Solid State Nuclear Track Detectors (SSNTDs) chips housed in a special diffusion chamber. The detectors were manufactured at the Radon Services Laboratory (IRP) of the Centre for New Technology, Energy and Environment (ENEA), Italy. The dimension of the chips was $7.5 \mathrm{~cm} \times 5.5 \mathrm{~cm}$ $\mathrm{x} 3.5 \mathrm{~cm}$, placed in diffusion chambers that are domeshaped with on and off twists. The CR-39 was placed in the chamber, turned on to allow radon-laden air into the chamber, and prevents the entry of short-lived isotopes of radon (Kaliprasad and Narayana, 2019). They were hanged at a distance of $1 \mathrm{~m}$ from the ceiling and at least $30 \mathrm{~cm}$ from the walls and left for 90 days. Thereafter, the chambers were turned off and the chips were removed for etching and counting. The recovery rate of the chamber was $84 \% ; 16 \%$ were lost due to damages and violations of the exposure procedures.

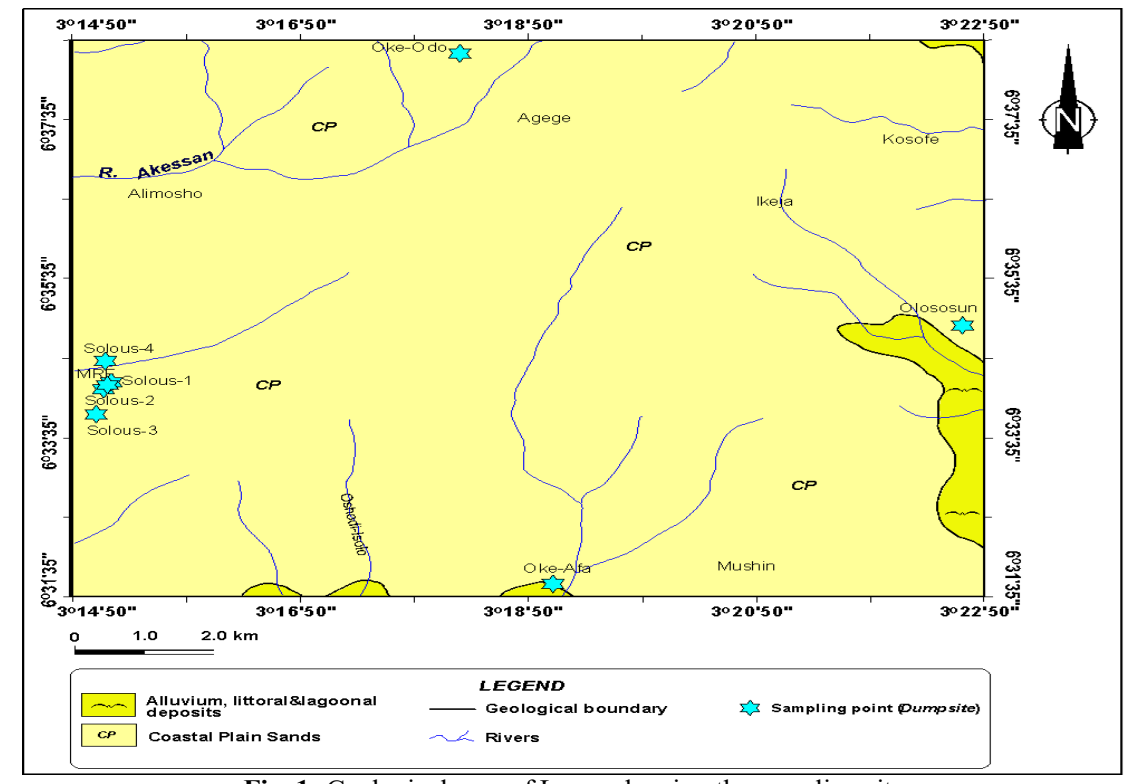

Fig. 1: Geological map of Lagos showing the sampling sites

Etching and counting of tracks: The chips were etched in a $6 \mathrm{M} \mathrm{NaOH}$ solution in a water-bath at an even temperature of $90^{\circ} \mathrm{C}$ for 3 hours. They were washed under running water for 10 minutes and then placed in distilled water. After 30 minutes, the detectors were removed, placed on gauss papers, and left to dry overnight in the laboratory.

After etching, tracks on the detectors were viewed and captured using a microscope coupled with a DCE camera at a magnification of $x 40$. The pictures of the views were taken and saved on the PC and tracks on them were counted using ImageJ software. Equation 1 was used to convert the tracks on the chips to radon concentration.

$$
R_{n}=\frac{T_{d} \times C_{F}}{T}
$$

Where Td is track density (tracks $\mathrm{mm}^{-2}$ ) and CF is the calibration factor $\left(\frac{\mathrm{Bqm}^{-3}}{\text { tracksmm }^{-2}}\right)$ day and $\mathrm{T}$ is the time i.e. (days of exposure)

Evaluation of Annual Effective Dose: The determinant of individual radiation exposure is the effective dose and It was estimated using equation 2 (UNSCEAR, 2007) 


$$
E_{D}(m S v)=R_{n} \times E_{F} \times O \times T \times D_{C F}
$$

where $R_{n}$ - concentration of radon $\left(\mathrm{Bqm}^{-3}\right), \mathrm{E}_{\mathrm{F}}$ - the equilibrium factor (0.4), $\mathrm{O}$ - the occupancy factor (0.7), T - time $\left(8760 \mathrm{hy}^{-1}\right)$ and $\mathrm{D}_{\mathrm{CF}}$ - dose conversion factor $\left(9.0 \times 10^{-6} \mathrm{mSv} / \mathrm{Bqm}^{-3} \mathrm{~h}^{-1}\right)$.

Cancer Risk (CR): Cancer risk to the lung that may lead to death per million persons per year (MPY) $)^{-1}$ due to exposure to radon was estimated using equation 3 .

$$
C R=E_{D} \times L_{E} \times \eta
$$

Where $E_{D}$ - effective dose $(\mathrm{mSv}), \mathrm{L}_{\mathrm{E}}$ - life expectancy in Nigeria (55 years) and $\dot{\eta}$ - the risk factor (UNFPA, 2019)

\section{RESULTS AND DISCUSSION}

Table 1 presented the concentration of radon in the buildings. In active dumpsites, radon concentration ranged from $24.00 \pm 4.86$ to $656.00 \pm 131.20 \mathrm{Bqm}^{-3}$ with a mean of $169.8 \pm 31.9 \mathrm{Bqm}^{-3}$. Mean radon concentrations in the active sites were $120.3 \pm 24.0$,
$257 \pm 51.4,179.8 \pm 33.6$, and $131.5 \pm 19.4$, respectively in Oke-Odo, MRF, Olusosun, and Solus-3. In the dormant dumpsites, radon concentrations ranged from $16 \pm 3.2$ to $931 \pm 186.3 \mathrm{Bqm}^{-3}$. The mean concentrations in the dormant dumpsites were 194.17 \pm 38.80 , $206.75 \pm 41.33,223.25 \pm 44.69$, and $334 \pm 66.85 \mathrm{Bqm}^{-3}$, respectively in Oke-Afa, Solus-1, Solus-2, and Solus4 , with a mean of $234.5 \pm 46.9 \mathrm{Bqm}^{-3}$. The comparison of radon concentration in the active and dormant dumpsites revealed high radon concentrations in dormant dumpsites than in the active dumpsites which may be due to continued decomposition and disintegration of radioactive materials in the dumpsites.

\begin{tabular}{|c|c|c|c|c|}
\hline & \multicolumn{4}{|c|}{ Dumpsites } \\
\hline & \multicolumn{2}{|c|}{ Active Dumpsite } & \multicolumn{2}{|c|}{ Dormant Dumpsite } \\
\hline & $\begin{array}{l}\text { Location/ } \\
\text { Dumpsites }\end{array}$ & $\begin{array}{l}\text { Mean Radon } \\
\text { concentration }\end{array}$ & $\begin{array}{l}\text { Location/ } \\
\text { Dumpsites }\end{array}$ & $\begin{array}{l}\text { Mean Radon } \\
\text { concentration }\end{array}$ \\
\hline 1 & Oke-Odo & $120.3 \pm 24.0$ & Oke-Afa & $194.2 \pm 38.8$ \\
\hline 2 & $\mathrm{MRF}$ & $257.0 \pm 51.4$ & Solus-1 & $206.8 \pm 41.3$ \\
\hline 3 & Olusosun & $179.85 \pm 33.6$ & Solus-11 & $223.3 \pm 44.7$ \\
\hline 4 & Solus-3 & $131.5 \pm 19.4$ & Solus-4 & $334.0 \pm 66.9$ \\
\hline & $\begin{array}{l}\text { Total } \\
\text { Mean }\end{array}$ & $169.8 \pm 31.9$ & $\begin{array}{l}\text { Total } \\
\text { Mean }\end{array}$ & $234.5 \pm 46.9$ \\
\hline
\end{tabular}

Table 1: Mean Radon Concentration in Active and Dormant

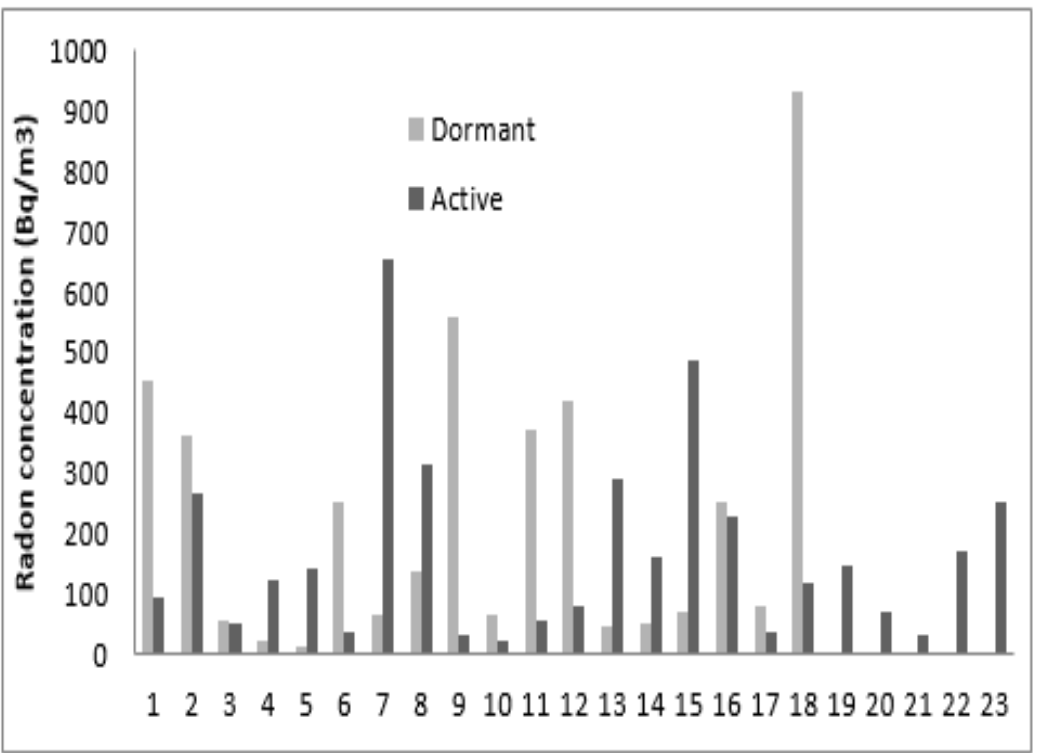

Fig 2: Comparison of radon concentration in the active and dormant building sites

Figure 3 shows the frequency distribution of radon concentration in the buildings. About $64.3 \%$ (27) of the building have radon concentration below $200 \mathrm{Bqm}^{-}$ 3; the lower limit of the recommendation for intervention. $14.3 \%$ have concentrations above $400 \mathrm{Bqm}^{-3}$, two-building have radon concentration above the ICRP intervention level (ICRP, 2007). The comparison of radon concentrations in the residential building showed that buildings within 0-50 meters have the highest radon concentration, although some buildings within 50 and 100 meters also showed high values which may be due to poor ventilation, building material, and water used in the buildings. Mean radon concentrations were 235.5 and $166.5 \mathrm{Bqm}^{-3}$ for buildings within 50 meters and buildings beyond 50 meters, respectively. The annual effective doses from exposure to radon in buildings in the vicinity of the dumpsites and the cancer risks associated with it are presented in Table 2. The annual effective dose in the buildings close to the active sites was $3.60 \mathrm{mSv} \mathrm{y}^{-1}$, 
while in the dormant sites it was $4.53 \mathrm{mSv} \mathrm{y}^{-1}$. These values lie within the recommendation of ICRP. In the active sites, the mean effective dose was $3.26 \mathrm{mSv} \mathrm{y}^{-1}$ while it was $3.83 \mathrm{mSv} \mathrm{y}^{-1}$ in dormant sites. The mean ELCR in the active sites was $8.97 \times 10^{-6}$ while it was
$10.72 \times 10^{-6}$ in dormant ones. These values were within the limit recommended of $1.0 \times 10^{-6}-1.0 \times 10^{-}$ ${ }^{4}$ (USEPA, 2003). The highest value of $17.38 \times 10^{-6}$ was recorded at Solus-4; a former medical waste facility.

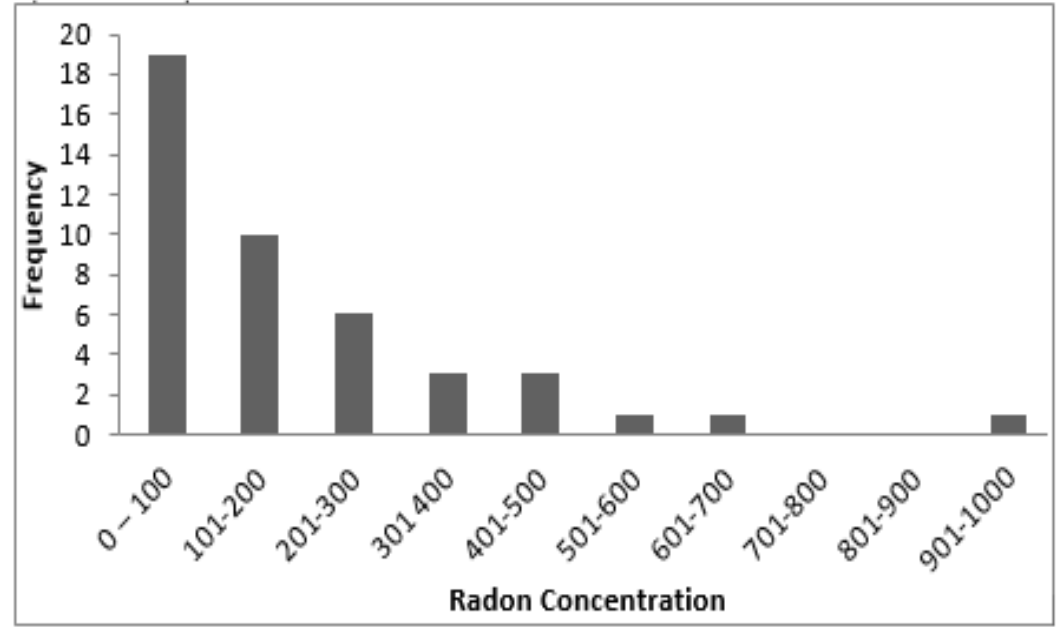

Fig 3: Frequency distribution of radon concentration in the residential building

Table 2: Mean Annual Effective dose (E-Dose) (mSV) and Excess Lung Cancer Risk (ELCR) (MPY) ${ }^{-1}$ in the Dumpsites

\begin{tabular}{lllllll}
\hline \multicolumn{2}{l}{ Active Dumpsite } & \multicolumn{4}{l}{ Dormant Dumpsite } \\
\cline { 2 - 7 } & $\begin{array}{l}\text { Location/ } \\
\text { Dumpsites }\end{array}$ & $\begin{array}{l}\text { E-Dose } \\
(\mathrm{mSv} / \mathrm{y})\end{array}$ & ELCR & $\begin{array}{l}\text { Location/ } \\
\text { Dumpsites }\end{array}$ & E-Dose & ELCR \\
\cline { 2 - 7 } 1 & Oke-Odo & 2.27 & 6.24 & Oke-Afa & 3.67 & 10.10 \\
2 & MRF & 4.86 & 13.37 & Solus-1 & 3.92 & 10.78 \\
3 & Olusosun & 3.41 & 9.38 & Solus-11 & 4.22 & 11.01 \\
4 & Solus-3 & 2.50 & 6.88 & Solus-4 & 6.32 & 17.38 \\
\hline & Total Mean & 3.60 & 8.97 & Total Mean & 4.53 & 12.47 \\
\hline
\end{tabular}

Conclusion: This study measured indoor radon in buildings in the vicinity of some waste dumpsites in Lagos, Nigeria. It was revealed that the concentration of radon in the buildings varied with distance and type of dumpsites. It can be concluded, that the residents of building in the vicinity of the dumpsites may be at risk of contracting lung cancer due to continuous radon exhalation from the dumpsite.

\section{REFERENCES}

Adegbenga, BA; Abiola, A; Arinipade, I; Jokotade, A; Babatope; K (2017). Pattern of Underweight and Overweight in Lagos Southwest Nigeria. J. Appl. Biotechnol. Bioeng. 4(2):534-538.

Ajrouche, R; Roudier, C; Cléro, E; Ielsch, G; Gay, D; Guillevic, J; Laurier, D (2018).Quantitative health impact of indoor radon in France. Radiat. Environ. Biophys. 57(3): 205-214

Benson, ID; Ugbede, FO (2018). Measurement of background ionizing radiation and evaluation of lifetime cancer risk in highly populated motor parks in Enugu City, Nigeria. J. Appl. Phys. 10(3): 77-82.

Ciorba, D; Fodor, E; Cosma, C; Albert-Ani, D; Moldovan, M (2017). Testing of Individual Sensitivity to Radon And Thoron Exposure by In Vitro Irradiation of Lymphocytes Culture. Studia UBB, Ambientum. 62(1): 9-27

Corrales, L; Rosell, R; Cardona, AF; Martín, C; Zatarain-Barrón, ZL; Arrieta, O (2020). Lung cancer in never smokers: The role of different risk factors other than tobacco smoking. Cri. Rev. Oncology/Hematology.148: 102895

Dai, D; Neal, FB; Diem, J; Deocampo, DM; Stauber, C; Dignam, T (2019). Confluent impact of housing and geology on indoor radon concentrations in Atlanta, Georgia, United States. Sci. Tot. Environ. 668: 500-511.

Grganić, H; Grgić, D; Šadek, S (2020). Room Classification Based on EMC Conditions in 
Nuclear Power Plants. Energies. 13 (2):359

ICRP (2007). The 2007 recommendations of the international commission on radiological protection (ICRP). In ICRP publication 103, Ann. ICRP 2007.

Kaliprasad, CS; Narayana, Y (2019). Radon exhalation rate and radon activity in soils ofriverine environs of South Karnataka. Radiat. Prot. Environ. 41(4): 189-191

Kim, SH; Hwang, WJ; Cho, JS; Kang, DR (2016). Attributable risk of lung cancer deaths due to indoor radon exposure. Annals Occu. Environ. Med. 28(1): 8

Kumar, A; Sharma, S; Mehra, R; Narang, S; Mishra, $\mathrm{R}$ (2017). Assessment of indoor radon, thoron concentrations, and their relationship with seasonal variation and geology of Udhampur district, Jammu \& Kashmir, India. Int. J. Occu. Environ. Heal. 23(3): 202-214

Rasouli, J; Mamkhosravi, S (2018). The Role of Radon in Some Drinking Water Pollution in Bukan (northwest Iran). Arch Pet Environ Biotechnol: APEB-126

Shankar, A; Dubey, A; Saini, D; Singh, M; Prasad, CP; Roy, S; Khanna, M (2019). Environmental and occupational determinants of lung cancer. Trans/lung cancer res, 8(Suppl 1), S31

Stanley, FK; Zarezadeh, S; Dumais, CD; Dumais, K; MacQueen, R; Clement, F; Goodarzi, AA (2017). Comprehensive survey of household radon gas levels and risk factors in southern Alberta. CMAJ Open, 5(1), E255
United Nations Scientific Committee on the Effects of Atomic Radiation. (2000). Sources and Effects of Ionizing Radiation. Report to the General Assembly, (New York: United Nations).

Available at: www.unscear.org > docs > publications > $\underline{\mathrm{UNSCEAR} / 2000}$

United Nations. Scientific Committee on the Effects of Atomic Radiation. (2007). Health effects due to radiation from the Chernobyl accident. UNSCEAR

United Nations Fund for Population Activities. UNFPA (2019). Annex 4 UNFPA engagement of faith-based and religious actors, 2018. Annual report

United State Environmental Protection Authority (2003). A Consolidated Emissions Modeling System for MOBILE6 and NONROAD, US Environmental Protection Agency, Office of Transportation and Air Quality, National Mobile Inventory Model (NMIM)

Zhang, Y; Hou, D; O’Connor, D; Shen, Z; Shi, P; Ok, YS; Tsang, DSW; Wen, Y; Luo, M (2019). Lead contamination in Chinese surface soils: Source identification, spatial-temporal distribution, and associated health risks. Cri. Rev. Environ. Sci. Tech. 49(15):1386-1423. 